\title{
Reflective Journal: The Learners' Perspective in Formal Instruction
}

\author{
Rosa May-Melendez, MA. \\ Universidad Autónoma Del Carmen, Mexico \\ Myrna Balderas-Garza, MA. \\ Eloisa Alcocer-Vazquez, PhD \\ Universidad Autónoma De Yucatán, Mexico \\ Gandy Quijano-Zavala, PhD \\ Universidad Autónoma Del Carmen, Mexico
}

Doi:10.19044/esj.2019.v15n10p252 URL:http://dx.doi.org/10.19044/esj.2019.v15n10p252

\begin{abstract}
As part of the evaluation process, some strategies are implemented to foster students' learning in the English Language Teaching Degree. Professors from a Universidad Autónoma located in the South part of Mexico are conducting action research based on the new educational model in which reflective journal is one of those strategies to be developed, therefore, a study based on the use of reflective journal learning in a course was carried out. The purpose was to investigate if learners find it useful during their learning process and their willingness to use it in all courses. In order to gather data, researchers designed a weekly reflection sheet where students were asked to provide their reflections about the topics and the difficulties found during the summer course, which is a course from the curricula. After the analysis of the information, researchers noticed that students found the use of reflective journals productive for their learning; however, they do not want to use them in all the courses. In conclusion, although reflective journals from students' perspectives are useful, it is a strategy that requires time and they do not want to use them for all the courses, hence the professors will have to vary this strategy among the courses.
\end{abstract}

Keywords: Reflective journal, students' learning, English Language Teaching degree, educational model, learning strategy

\section{Introduction:}

Scrivener (2005) suggests to study our own teaching practice through feedback, reflection and action research, also Edwards and Burns (2016) states that action research (AR) is becoming popular in the English Language 
Teaching area, because it is taken as a mean of continuous Education or professional development. The use of reflective journal has gained some popularity in the language classroom, since it is a useful strategy to support the teaching of certain areas due to the fact that it enhances learning assessment and, therefore, allows the learner make judgments of his/her own progress.

According to Boud, Keogh and Walker (2005, p.8) reflecting on our activities is part of our daily life: "We need time to catch up with ourselves, to make sense of what has happened, or to share other people's ideas on an experience," which is to say that we all reflect during the day through our daily activities.

As future language teachers our students need to learn how to use a reflective journal to record their own learning and practice. As Henter \& Indreica (2014) point out, teachers and students are moving toward more formative assessment, and new strategies of achieving this are required. One such strategy is the reflective journal, which turns out to be a useful tool now, as students record their own learning progress, and later on, as teachers evaluate their own performance.

Reflective journals are personal notes of students' learning experiences. Entries in journals can be prompted by questions designed by the professor about the course, tasks, or ideas from the students, and they are submitted to the teacher for feedback; whether the journals are graded or not depends on the professor's criteria. (Northern Illinois University, p.1)

In addition, the reflective journal causes positive effects in our students' learning from the professor's view, since it can be used to monitor metacognitive dimensions and encourage reflection on their own strengths and weaknesses while or after performing an activity, as it is the case of this action research (Henter \& Indreica, 2014).

Moon's (2010) proposal on language learning and reflective journal is based on the "written work of students such as video summaries, vocabulary lists and self-reflective comments." It is a process that involves learners as well as teachers, leading towards the goal of language learning autonomy.

\section{Research approach}

This study was conducted through a qualitative approach since our main concern was focused on students' reflections and attitudes towards writing reflective journals after every learning sequence and at the end of the course. Additionally, the interest of the researchers was to encourage students' learning opportunities, as well as strengthening the use of these reflective strategies; after all, this approach aims to see the world from the participants' perspective (Corbin \& Strauss, 2008, as cited in McKenzie, S., n.d.) 
As part of this approach, our proposal is based on action research since our objective and the specific activities involved in our project involve the students' use of reflective journals to reflect on their learning process. AR has been also demonstrated to be an effective model for developing teachers as leaders of change in their practice and reflective practitioners (Saleem, 2018), Moreover, we aimed to find out how useful students found reflective journaling and how willing they would be to use this strategy in all their courses.

According to Wallace (1999, p.16) action research "involves the collection and analysis of data related to some aspect of our professional practice." Therefore, aware of the students' needs, and our objective to train them in the use of a reflective journal as a learning strategy, research was implemented for the students, as described in the corresponding section of this paper.

To gather information for analyzing if the objectives of our research study were fulfilled, a reflection guide followed by feedback, and a questionnaire were administered during the course. Therefore, each participant ended up with a total of four reflections at the end of the course, as well as a final questionnaire to determine the usefulness of using reflective journal in class. The reflection questions asked students to report what they had learnt, what had gone well, what they could have done better, and how they would apply what they had learnt.

\section{Subjects}

The study was carried out on 23 Mexican students of the Faculty of Educational Sciences in the English Language Teaching degree program whose mother tongue is Spanish. Most of them have been studying English since secondary school due to the Mexican public education system, where English is taught compulsorily from junior high school, unlike private institutions, where English is part of the curricula from kindergarten.

The subjects' age range was from 20 to 23 years old, and they are currently enrolled in different semesters, from $5^{\text {th }}$ to $8^{\text {th }}$. There were 5 male and 18 female subjects; students enrolled in the degree program are mostly women, which is why, in most courses, women are predominant.

\section{Research process}

The participants chosen were students enrolled in the Motivational Strategies for Teaching English course, which is a course that students can take during summer, once the term or the semester has come to an end. The reflective journal is a strategy used for assessment according to the new educational model of the institution therefore, this strategy was to be used after every sequence (learning unit). 
The students were asked if they had used a reflective journal previously. Fortunately students had already had the experience, which was an advantage for the researchers. Due to students' familiarity with the process, it was unnecessary to explain the how-to of keeping a reflective journal; however, students were told they had to answer several questions that would be analyzed by the professors after each finished lesson.

The course lasted 4 weeks, so students were instructed on how to begin writing their reflective journals the first day of the first week. They were told to use an old notebook, or make one for themselves, which would be used as a diary to record their reflections after each lesson.

At the end of every week, each participant recorded his/her own information in a diary by responding to four main questions focused on their perception of what they learned and what presented a challenge to them. At the end, students' records of their attitude toward the use of reflective journals and their usefulness in class were recorded by students.

\section{Results}

As aforementioned, on the first week students were instructed on how to write their reflective journal. They were asked if they were familiarized with this strategy and mentioned they had already used it in another class the previous semester, however, in that class they were asked to add references to their reflective journal.

Even though they had already used it, they were told to use it in a specific way for the sake of the study; this time they just had to record their entries weekly and provide simple answers to four questions about their learning progress; students were told they could write as much as they wished about each question.

All 23 students of the course finished with a passing grade without missing any entries. The reflective journal was $20 \%$ of their total grade, hence, students would lose points, affecting their final grade, if they did not submit the journal on time.

After the first unit, students had to write their reflections based on the following questions, presented in table 1.1 and 1.2, with some examples of students' entries, based on the first and second unit. 
Table 1.1. $1^{\text {st }}$ week. Students' entries of their reflective journals

\begin{tabular}{|c|c|}
\hline W1 & Reflection on the first week \\
\hline $\begin{array}{l}\text { What did I } \\
\text { learn? }\end{array}$ & $\begin{array}{l}\text { S1 we learnt more about classroom management topics...like } \\
\text { emotional intelligence... } \\
\text { S2 Another thing that I have learned are the strategies that the teacher } \\
\text { was using during class. } \\
\text { S3 I learnt many characteristics and strategies regarding English } \\
\text { language teaching and learning. }\end{array}$ \\
\hline What went well? & $\begin{array}{l}\text { S1 it contributed with my experiences as a self-learner of Asian } \\
\text { Languages and English. } \\
\text { S2 It is fun in the class because we are engaged to participate, it is not } \\
\text { common that teachers do this in our classes. } \\
\text { S3 I contribute to the topics seen by giving my point of view. }\end{array}$ \\
\hline $\begin{array}{lr}\text { What could I } \\
\text { have } \\
\text { better? }\end{array}$ & $\begin{array}{l}\text { S1 ... (she skipped this question) } \\
\text { S2 Is the second exposition because we were organized but some } \\
\text { people at the end worked with us and it was confusing for us at the } \\
\text { moment to explain the information. } \\
\text { S3 I could have said more or I could have contributed more to the } \\
\text { topics discussed in class. }\end{array}$ \\
\hline $\begin{array}{l}\text { Long-term } \\
\text { implications } \\
\text { (How would you } \\
\text { apply what you } \\
\text { have learnt? }\end{array}$ & $\begin{array}{l}\text { S1 I would like to know how to manage better my class and encourage } \\
\text { them to read or talk... } \\
\text { S2 I will used the strategies the teacher used with us. I will everything } \\
\text { that I learn in this subject. } \\
\text { S3 I think the topics seen in class will help me develop teachers' skills } \\
\text { in the class... create a motivational atmosphere in the classroom... }\end{array}$ \\
\hline
\end{tabular}

Another example from week two, given in table 1.2, present students' real reflections from their learning process and their perceptions of the class.

Table 1.2 2nd week. Students' entries of their reflective journals

\begin{tabular}{|c|c|}
\hline W2 & Reflection on the second week \\
\hline $\begin{array}{l}\text { What did } \quad \text { I } \\
\text { learn? }\end{array}$ & $\begin{array}{l}\text { S4 Even when a game seem to be easy to perform, instructions are a } \\
\text { key factor for the success } \\
\text { S5 The reading materials were very enriching. I learned many } \\
\text { different dynamics that can be implemented in a class. } \\
\text { S6 I learned a lot about the importance of using games in the English } \\
\text { classroom. }\end{array}$ \\
\hline What went well? & $\begin{array}{l}\text { S4 The organization of the role plays and I dare to say the instructions } \\
\text { weren't bad. } \\
\text { S5 I consider that the simulations of the games were ideal to see how } \\
\text { useful the games could be. } \\
\text { S6 ... (she skipped this question) }\end{array}$ \\
\hline $\begin{array}{l}\text { What could I } \\
\text { have } \\
\text { better? }\end{array}$ & $\begin{array}{l}\text { S4 I have to plan all the instructions and possible implications. } \\
\text { S5 What I can improve is my attendance... } \\
\text { S6 I could have done a better job at the moment of giving instructions. }\end{array}$ \\
\hline $\begin{array}{l}\text { Long-term } \\
\text { implications } \\
\text { (How would you } \\
\text { apply what you } \\
\text { have learnt? }\end{array}$ & $\begin{array}{l}\text { S4 Games can help to create a fun environment in the learning process } \\
\text { and in the language teaching area. } \\
\text { S5 I would apply almost all the games and warm-ups seen in class. } \\
\text { S6 I think I would use games more often and not just for having fun in } \\
\text { the class, but also for learning. }\end{array}$ \\
\hline
\end{tabular}


Table 1.3 Final students' reflection

\begin{tabular}{|c|c|}
\hline Final & Reflection on the whole course \\
\hline $\begin{array}{l}\text { What did I } \\
\text { learn? }\end{array}$ & $\begin{array}{l}\text { S1 I learn how some activities are better, or more interesting to a } \\
\text { specific age group or kind of students. } \\
\text { S2 Creativity, motivation, strategies and games } \\
\text { S3 How to put in practice the theory }\end{array}$ \\
\hline What went well? & $\begin{array}{l}\text { S1 The activities, I think that performing the activities, put them in } \\
\text { practice, made me realize the success or adaptability of these } \\
\text { activities. } \\
\text { S2 Homework, } \\
\text { S3 The class environment... The class was respective and } \\
\text { collaborative. }\end{array}$ \\
\hline $\begin{array}{l}\text { I could have } \\
\text { done a better job } \\
\text { if... }\end{array}$ & $\begin{array}{l}\text { S1 I had prepared better when doing the activities. } \\
\text { S2 I had studied more in the quizzes. } \\
\text { S3 I had worked with different people, I think that if we had varied } \\
\text { teams. }\end{array}$ \\
\hline $\begin{array}{l}\text { Long-term } \\
\text { implications } \\
\text { (How would you } \\
\text { apply what you } \\
\text { have learnt? }\end{array}$ & $\begin{array}{l}\text { S1 These are good for actually do in class. } \\
\text { S2 By teaching according to the games to make my classes more fun. } \\
\text { S3 In my students' activities and future micro-teaching. }\end{array}$ \\
\hline
\end{tabular}

Students' comments in their entries were very straightforward; actually, they were aware of the fact that their participation and learning was mostly their duty. Moreover, they made positive comments: for instance, if they thought that they had done a good job or if they thought that they had to work harder, they would write it.

The last day of the course, the students were given a questionnaire in order to find out if they found the reflective journal useful for their learning process. Table 1.3 below summarized students' responses:

Table 1.3 Students opinions about the use of reflective journal

\begin{tabular}{|l|l|}
\hline It is a good tool & 20 students \\
\hline It helped me a little & 3 students \\
\hline It is not useful & 0 student \\
\hline
\end{tabular}

Overall, most students found the reflective journals a useful tool to keep a record of their learning. This data matches with the professor's feedback on the weekly journals where students reflected on their learning process and final outcomes.

Their opinion and perspectives towards reflective journals are shown in the following table (Table 1.4) 


\begin{tabular}{|l|l|l|l|}
\hline My journal helped me... & $\begin{array}{l}\text { Yes of } \\
\text { s of } \\
\text { students }\end{array}$ & $\begin{array}{l}\text { No } \\
\text { students of } \\
\text { stud }\end{array}$ & $\begin{array}{l}\text { I do not know } \\
\text { \# of students }\end{array}$ \\
\hline $\begin{array}{l}\text { To record significant experiences, including } \\
\text { associated feelings and thoughts. }\end{array}$ & 23 & 0 & 0 \\
\hline To appreciate learning and celebrate success & 22 & 0 & 1 \\
\hline To respond to new ideas & 20 & 0 & 3 \\
\hline To examine assumptions, beliefs and values & 20 & 0 & 3 \\
\hline To consider alternative perspectives & 18 & 1 & 4 \\
\hline To develop personal theories & 16 & 4 & 3 \\
\hline To take thoughtful action in my learning & 22 & 0 & 1 \\
\hline I would use reflective journals in all my classes & 8 & 6 & 9 \\
\hline
\end{tabular}

Table 1.4. Students' perspective towards reflective journal

Not only did students agree that the use of a reflective journal was a good tool, but they also agreed on the fact that it was very helpful for their learning process, which is congruent with what Moon (2006, p. 4) states, "reflection is associated with deep approaches to learning." Some positive comments made by students were "I believe that reflective journal are helpful to reinforce the information we have learnt" "We used reflective journal before but we had to add references, and I did not like it, I prefer it this way, I can write freely". However, in the last written question, where students were asked whether they would use reflective journals in all their classes, most of them did not agree. In addition, there was a note made by a student at the end of the page: "I think journals are very useful and help with creative and critical thinking, the problem here is, we don't have enough time to consciously write them. Especially during semester Table 1.3 Final students' reflection. "Evidently, time is one of the reasons these students do not want to use reflective journals as a learning tool in all classes.

\section{Discussion}

Regarding the use of reflective journal for learning, students found it very useful; it is a tool where they feel free to write as many ideas and feelings as they can; it is a space for recording their learning processes; and it allows them to recall important information from previous courses and easily relate it to new knowledge.

In addition to the positive outcomes our subjects cited, there are even more positive outcomes when using these journals, as Farrah (2012) mentions: it can be beneficial for improving English writing skills, increasing motivation, enhancing creativity, and critical thinking. Moreover, reflective journaling helped improve students' confidence, and we realized that students were able to accept their mistakes and commit themselves to change.

Despite finding this tool useful and helpful, students do not want to use reflective journals in all their lessons, mostly due to the limited time they have 
during their busy semester; this concern is understandable because students enroll in several subjects and each one has its own demands; willingly adding a reflective journal component to their demanding course load appears to be too time consuming. It was clear that students needed time to write their reflections, they need to time to think carefully about their previous knowledge, the process of learning, their failures and areas for improvement, and how the current knowledge can lead them to succeed in their teaching practice.

The outcomes were positive and, although the final grades were varied, they ranged from average to excellent. No one failed or missed any entry of their reflective journal, most likely because they were aware that their entries counted as $20 \%$ of the final grade. But, ultimately, it is students' decision what assignments to turn in.

\section{Conclusion}

Previous research agrees on the advantages that learning reflection brings into the classroom. The way a professor uses the reflective journal depends on the objectives and aims he or she wants to achieve. Acording to Mathew, Mathew and Peechattu (2017) 'A person who reflects throughout his or her practice is not just looking back on past actions and events, but is taking a conscious look at emotions, experiences, actions, and responses, and using that information to add to his or her existing knowledge base and reach a higher level of understanding'.

Shih's (n.d.) outcomes of her action reseach project showed that students confirm that writing a reflective learning journal helped them learn more about the subject. It is definitely a useful tool to use in the classroom, no matter the subject. Reflection will always be worth encouraging if we want our students to recall what they have just learnt, how they did in class, regarding their learning and participation, and, most important, how that knowledge can be applied in their future learning and practice.

To sum up, reflective journals could be used during winter or summer courses, or with two courses during the regular semester, so as to avoid adding stress and time demands to students' busy schedules. As a tool that has numerous advantages, we as teachers do not want our students to get frustrated with compulsory reflective journal requirements in every course. Instead, we should judiciously encourage students to keep reflective journals as often as they can and promote their effectiveness as a tool to reflect on their own developing teaching practices as well.

\section{References:}

1. Boud, D., Keogh, R., \& Walker, D. (2005) Reflection: Turning Experience into Learning. London. Routledge: Falmer. 
2. Edwards, E., \& Burns, A. (2016) Language teacher action research: achieving sustainability, ELT Journal. 70. 1. (1). 6-15.

3. https://doi.org/10.1093/elt/ccv060

4. Farrah, M. (2012) Reflective Journal Writing as an Effective Technique in the Writing Process. 26. (4). 998-1025.

5. Henter, R., \& Indreica, E., (2014) Reflective Journal Writing as a Metacognitive tool. International Conference of Scientific Paper.

6. Mathew, P. Mathew, P \& Peechattu, P. (2017) Asia Pacific Journal of Contemporary Education and Communication Technology (APJCECT).

7. 3 (1) Retrieved from https://apiar.org.au/wpcontent/uploads/2017/02/13_APJCECT_Feb_BRR798_EDU-126131.pdf

8. McKenzie, S.(n.d) Research Methods: Qualitative approach. Retrieved from https://www.downstate.edu/geriatricfellowship/documents/Qualitati veResearchMethods_DownstatePresentationSTUDENT.pdf.

9. Moon, J. (2006) Using Learning Journals with students: some guidance materials for tutors or those writing journals. Centre for Excellence Media practice. Bournemouth University

10. Northern Illinois University, Faculty Development and Instructional Design Center. Retrieved from

11. https://www.niu.edu/facdev/_pdf/guide/assessment/reflective_journ als\%20and_learning_logs.pdf

12. Saleem, M. (2018) Action Research as a Reflective Tool for Teachers in a Multicultural Education Class. 15 (1) 1-10. Retrieved from : https://scholarworks.gvsu.edu/colleagues/vol15/iss1/6

13. Scriver, J. (2005) Language teaching a guidebook for English Language Teaching. Oxford: Mcmillan.

14. Shih, C (n/d) Learning from writing reflective learning journals in a theory-based translation module: students' perspectives.

15. Wallace, M. (1999) Action Research for Language Teachers. Cambridge: Cambridge University Press. 